\title{
Amor, consumo e sexualidade: o que as mulheres querem?
}

\section{Love, consumption and sexuality: What Women Want?}

Túlio Cunha Rossi ${ }^{1}$

\section{Resumo}

Apresenta-se uma análise interpretativa da produção cinematográfica "Do que as mulheres gostam", tendo por base a metodologia de análise fílmica em Sociologia, proposta por Pierre Sorlin (1982), que toma o filme como uma construção de sentidos que evoca discursos e signos, mais ou menos reconhecidos no meio social, tanto de produção quanto de público pretendido. A partir disso, objetiva-se problematizar a construção e a reprodução de estereótipos de gênero, explorando possíveis relações entre consumo, sexualidade e imagens, tanto do masculino quanto do feminino. Realiza-se, por fim, uma análise de duplo enfoque a partir da narrativa fílmica, discutindo-se os elementos socioculturais presentes dentro do filme e como eles expressam questões mais amplas, entrelaçando a construção social da realidade à construção cinematográfica de valores, signos e relações entre sexos.

Palavras-chave: Gênero. Afetividade. Consumo. Indústria cinematográfica. Construção social da realidade.

\begin{abstract}
It is presented an interpretive analysis of the film What Women Want, based on the methodology of film analysis in sociology proposed by Pierre Sorlin (1982), taking the film as a construction that evokes discourses and signs more or less recognized both in the social context of production and audience. From this, we aim to discuss the construction and reproduction of gender stereotypes, exploring possible relations among consumption, sexuality and images, both of masculine and feminine. Finally, it is done an analysis of double focus on the filmic narrative, discussing the social and cultural elements present within the film and how these express broader issues, intertwining the social construction of reality in the cinematography construction of values, signs and relationships between sexes.
\end{abstract}

Keywords: Gender. Affectivity. Consumption. Film industry. Social construction of reality.

\section{Introdução}

Este artigo consiste em uma análise sociológica do filme "Do que as mulheres gostam" (What Women Want, 2000), ${ }^{2}$ com ênfase na reprodução de estereótipos de

\footnotetext{
1 Universidade Federal da Paraíba (UFPB). Pós doutorando em Sociologia no Projeto Sem Reservas, na
} Universidade Federal da Paraíba (UFPB). E-mail: tuliorossi@gmail.com. 
gênero e de ideais de amor romântico hollywoodianos, a partir da metodologia e das reflexões desenvolvidas na tese "Projetando a Subjetividade: A construção social a partir do cinema" (ROSSI, 2013). Analisando a construção da narrativa fílmica, amparada na reprodução de símbolos e discursos reconhecidos no senso comum, problematizam-se relações culturalmente estabelecidas na contemporaneidade entre consumo, gênero e identidades e tomadas como expressões naturais da própria sexualidade.

A relevância analítica do filme reside em como ele apresenta mudanças de comportamento e percepção do protagonista quando, inexplicavelmente, ele adquire o dom de ouvir pensamentos femininos. Em acréscimo, o sucesso de bilheteria, suas reprises em canais de televisão e o prestígio do ator principal, Mel Gibson, como um dos símbolos masculinos de maior sucesso do cinema dos anos 1990, indicam se tratar de um filme bastante conhecido que mobiliza discursos e opiniões, em alguma medida, aceitos e às vezes partilhados por muitos espectadores. Trata-se então de uma construção que utiliza referências simbólicas, discursos e imagens amplamente reconhecidos e compartilhados pelos espectadores, de maneira que o estudo de sua produção necessariamente conduz a reflexões que extrapolam o universo diegético para penetrar numa análise do cotidiano e das significações de hábitos de consumo, distinções de gênero e relacionamentos afetivos influenciadas também pelas mídias cinematográficas, televisivas e pelas campanhas publicitárias por elas propagadas.

A análise resgata trechos significativos do filme e os discute dentro de seu encadeamento com o restante da narrativa, de forma a constituir mensagens e posicionamentos morais que expressam características e percepções tanto do meio no qual o filme é produzido quanto para o qual é produzido, promovendo um diálogo constante com abordagens sociológicas das temáticas de gênero, consumo e sociologia das emoções.

2 O título brasileiro parece suavizar a questão proposta: "O que as mulheres querem". Gostar tem a ver com agradar, enquanto o verbo querer é mais enfático; não se trata de algo vago que pode agradar alguém, mas de uma vontade, objetivo ou desejo, normalmente mais específico. Querer implica demanda, o que pode facilmente assumir caráter de reinvindicação, particular ou coletiva. Assim, a versão brasileira parece preservar uma certa banalização do querer feminino para transformá-lo em uma espécie de capricho, de simples apreciação de gosto.

Cad. de Pesq. Interdisc. em Ci-s. Hum-s., Florianópolis, Santa Catarina, ISSN 1984-8951 v.15, n.106, p. 59-90 - jan./jun. 2014 


\section{A (des)construção cinematográfica de relações naturalizadas entre os sexos}

A mobilização de signos reconhecidos pelo grande público, no tocante a questões de gênero, nesse filme já começa pela escolha de seu ator principal. Mel Gibson, sem dificuldades, pode ser visto como ícone de masculinidade do cinema dos anos 1980 e 1990, de forma que a escolha do ator para viver essa personagem que se "feminiliza" potencializa a construção cômica baseada, ao mesmo tempo, na reafirmação e no rompimento da imagem estabelecida ao longo de sua carreira precedente. Mel Gibson se consagrara a partir de filmes considerados tipicamente voltados ao público masculino, com destaque para as franquias "Mad Max" (1979, 1981, 1984) e "Máquina Mortífera" (Lethal Weapon, 1987, 1989, 1992, 1998). Nesse sentido, o ator cumpre a função que Jarvie (1974, p. 298) atribui às estrelas de cinema de:

[...] estabelecer pontos de referência fixos ou de familiaridade para o espectador. A imagem que este tem de um novo filme é, sem dúvida, bem mais vaga. Mas se nele figuram estrelas, o campo de suas expectativas poderá se ampliar consideravelmente, pois, ao menos, ele conhece o aspecto e a voz dos protagonistas.

Destarte, tem-se um referencial cinematográfico de "masculinidade" bem claro, com o qual o filme joga para criar suas situações cômicas, ao aproximá-lo de um universo construído caricatamente como mais "feminino". Mais do que caracteres tomados por naturais, tratam-se, na verdade, de construções partilhadas de masculinidade que levam a presumir comportamentos e modos de "ser". Conforme Connell (1995, p. 67),

em seu uso moderno, o termo [masculino] presume que o comportamento de alguém resulta do tipo de pessoa que se é. Isso quer dizer que, uma pessoa não masculina se comportaria diferentemente: sendo mais pacífica do que violenta, conciliatória do que dominadora, pouco hábil para chutar uma bola de futebol, desinteressada em conquista sexual e assim por diante.

O filme investe então nessa imagem estabelecida de Mel Gibson e a reforça, apresentando Nick, a princípio, como "o cara", ${ }^{3}$ enquanto homem que encarna, entre

3 "A men's man".

Cad. de Pesq. Interdisc. em Ci-s. Hum-s., Florianópolis, Santa Catarina, ISSN 1984-8951

v.15, n.106, p. 59-90 - jan./jun. 2014 
essas características "masculinas", principalmente a do interesse quase irrefreável pela conquista sexual.

Partindo do referencial de análise fílmica de Sorlin (1982), o filme é problematizado a partir da identificação e desconstrução dos sistemas relacionais, que, segundo o autor, tratam de construções específicas internas ao filme de grupos, redes de hierarquias e influências pelas quais as relações entre personagens se articulam, definindo posicionamentos morais, objetivos e desafios. Nesse sentido, a princípio, há dois grupos apresentados na maior parte do filme como antagonistas: homens e mulheres, sendo Nick o principal representante do primeiro. Além de Nick, há apenas outras três personagens masculinas, ${ }^{4}$ muito superficialmente construídas, todas de maneira que se aproxima à imagem de masculinidade personificada por Nick: Morgan, colega de trabalho mais jovem que se espelha e se inspira em Nick, Dan, chefe de Nick, com quem há uma relação muito próxima e, por último, Cameron, rapaz de 18 anos que namora a filha de Nick e se revela interessado apenas em levar a garota para cama.

Esses três personagens são construídos de forma a reforçar um estereótipo de masculinidade carregado de elementos considerados machistas, numa relação com o feminino orientada prioritariamente pelo sexo e por sua objetificação, mais claro nos anúncios publicitários pelos quais Nick é reconhecido, consistindo em mulheres sensuais com poucas roupas. Isso aponta para uma construção monolítica da masculinidade em seus piores aspectos, incorrendo no erro apontado por Connell (1995) de reduzir a masculinidade a um grupo de comportamentos e postura específicos, quando se há uma diversidade de noções e comportamentos masculinos por vezes contraditórios, sendo que muitos desses se firmam sem negar uma identificação masculina, como, por exemplo, no caso de homens que pouco se interessam por esportes e demonstrações de força física.

A construção inicial de Nick é feita indiretamente, a começar por sua esposa, que o define como "o cara", que serve de referência para todos os outros homens e que "simplesmente não entende as mulheres". Em seguida, por sua secretária, que o apresenta no ambiente de trabalho, como "o tipo daquele completo solteirão e o cara

\footnotetext{
${ }^{4}$ Não se inclui aqui o novo marido da ex-esposa de Nick por sua aparição consideravelmente rápida e inexpressiva no conjunto da narrativa, sendo praticamente um figurante.
} 
menos politicamente correto do universo. Ele é o rei de todos os anúncios tetas e bundas que fazemos". Por último, há o ponto de vista de sua filha que se refere a ele quase como um estranho, um "tio pai". A construção começa na condição de "exmarido", prossegue nas palavras de sua secretária que se refere a ele como "completo solteirão" e, por último, na fala da filha que mal o reconhece como pai. Essa sequência de depoimentos de pessoas relativamente próximas em esferas distintas afetiva/sexual (Gigi), trabalho (secretária) e família (Alex) - sugere Nick como um fracasso em termos de projeto de vida afetiva e familiar; embora a personagem, de início, não se perceba como tal. E, também nessa perspectiva, o filme já sublinha um posicionamento moral desfavorável à situação de "solteirão" - no caso, divorciado como expressão de uma falha de caráter a ser superada pela personagem.

Já a construção das personagens femininas no filme é consideravelmente mais plural: desde a estagiária suicida Erin, à Lola, atendente de cafeteria, passando pela filha de Nick, sua ex-esposa e Darcy (Helen Hunt). Contudo, quase todas as personagens femininas em interação com Nick ocupam alguma posição de subordinação a ele: sua empregada doméstica, a porteira de seu prédio, a filha menor de idade, a estagiária, a secretária, as duas assistentes e a atendente da cafeteria de onde ele é cliente. As exceções são a ex-esposa, que é apresentada já saindo oficialmente da vida de Nick ao casar-se novamente, e Darcy, com quem Nick não tinha nenhuma relação estabelecida anteriormente e que rompe com a estrutura anterior ao surgir já na condição de sua nova chefe. Com isso, tem-se a impressão de que, embora a caracterização feminina expresse diversidade e nuances, quase todas implicam numa subordinação ao poder masculino, tornando a posição de Darcy marcadamente atípica dentro daquela construção das relações de gênero, sendo que esse caráter atípico vai sendo desconstruído à medida que o filme permite o contato com os pensamentos dela e revelam fragilidade, inquietações em relação à afetividade, à emotividade e à sua imagem de chefe "durona".

Pela construção das práticas e pensamentos femininos que o filme explora, é como se reforçasse a ideia de que as mulheres estão prioritariamente interessadas em se relacionar afetiva e sexualmente ou em consumir. Mas, o aspecto da participação das mulheres nos hábitos de consumo não é algo particularmente novo ou resultante de 
uma liberação feminina recente. Campbell (2001, p. 45) já observara, no século XVIII, a relevante participação feminina no mercado consumidor, sobretudo de moda e livros de ficção.

Também há concordância generalizada de que a maior parte da procura provinha das classes médias, particularmente das mulheres. Como observa Taylor, o fato "de que as mulheres constituíam, de longe, a maior parte dos leitores desses romances nunca foi discutido". Esta última observação serve para se voltar a atenção para outro desenvolvimento sociocultural que ocorreu nesse período, a ascensão do amor romântico. Se se podia dizer que este foi uma "parte" da revolução do consumo, não está claro, mas ele esteve intimamente associado ao crescimento de um mercado para a ficção (CAMPBELL, 2001, p. 45).

De forma que a preocupação com a vida sentimental e a relação com consumo que o filme explora como caracteristicamente femininas não expressam em si uma mudança relevante nas percepções do comportamento feminino em final de século XX. Essa preocupação com a vida sentimental como caracteristicamente feminina é presente no filme desde o pensamento ouvido de uma moça que se pergunta se o fato de ter beijado uma amiga faz dela lésbica a pensamentos de Darcy como "não se apaixonar por alguém do trabalho". Pode-se interpretar que sua construção sugere que as mulheres pensam muito sobre sua vida afetiva - não necessariamente amor - e que grande parte de suas preocupações - mesmo no consumo - é ligada a isso, desde a compra de roupas e acessórios de beleza - batons, cera para depilação, meia calça e outros - que Ihes permitiriam sua inserção socialmente reconhecida enquanto objetos de desejo sexual masculino. Com isso, observa-se a reprodução de crenças socialmente enraizadas em relação a papéis de gênero que atribuem às mulheres uma inclinação naturalizada "a tratarem a si mesmas como objetos estéticos e, por consequência, prestar uma atenção constante à elegância do corpo, do vestuário e da manutenção [...]" (BOURDIEU, 1998, p. 97).

Tal inclinação, mais do que restrita à construção fílmica estereotipada da autoimagem feminina aqui presente, está profundamente ligada a uma construção social e histórica da feminilidade em relação ao masculino em que se coloca a realização feminina como que praticamente condicionada à união com um homem. $\mathrm{E}$, embora de início o filme pareça promover discursos afirmativos de ganho de poder pelas mulheres, colocando a personagem principal como chefe em uma grande

Cad. de Pesq. Interdisc. em Ci-s. Hum-s., Florianópolis, Santa Catarina, ISSN 1984-8951 v.15, n.106, p. 59-90 - jan./jun. 2014 
empresa e "dando voz" aos pensamentos que elas supostamente não ousariam pronunciar, ele reproduz estereótipos expressivos e conservadores de gênero persistentes. Nesse sentido, a análise dessa produção é emblemática para sublinhar, especialmente no cinema hollywoodiano, a manutenção de estereótipos de gênero que naturalizam uma inclinação feminina à afetividade, limitando o exercício legítimo de sua sexualidade e "do que elas querem" à conquista amorosa. Aliás, é importante ressaltar que masculino e feminino, devem ser considerados a partir de relações entre um e outro, e não como objetos fixos e naturais, como tendem a ser percebidas no senso comum (CONNELL, 1995).

Assim, o filme não constrói o pensamento feminino em relação ao sexo como dissociado da vida amorosa: Alex, filha de Nick, cogita perder a virgindade com seu namorado estando apaixonada, considerando que deve ser algo especial; Lola considera Nick atraente e o deseja sexualmente, mas os pensamentos que se ouve dela revelam preocupações afetivas, assim como a mulher que finge dor de cabeça para não fazer sexo com seu marido está inserida num contexto de vida conjugal. $O$ filme então insere a maioria desses pensamentos dentro de uma chave de envolvimento emocional específico, o que parece funcionar como justificativa moral para colocá-los sem comprometer a imagem romântica de mulheres como mais inclinadas ao amor do que ao sexo, imagem que Hollywood tende a reproduzir em suas comédias românticas.

Tal construção coloca e reitera o tema do amor e das emoções como algo caracteristicamente feminino, mobilizando caricatamente percepções em relação à afetividade, que tendem a colocar isso como assunto de maior preocupação para as mulheres do que para os homens. O protagonista só adquire a capacidade de se apaixonar depois de ter sofrido o acidente bizarro que lhe permitiu ouvir os pensamentos das mulheres. E só depois de algum tempo convivendo com essa capacidade e prestando atenção a desejos e inquietações não pronunciados pelas mulheres ele desenvolveu a sensibilidade que lhe permitiu notar Darcy - inicialmente uma oponente - como objeto romântico. E tal descoberta só é revelada com mais de uma hora de filme e dissociada de qualquer busca da personagem por um par romântico. O protagonista precisa sofrer uma transformação construída como mágica e 
absurda para se tornar capaz de amar, sendo que parte dessa transformação, como o filme sugere, não se restringe a ouvir o que as mulheres pensam, mas a se "feminilizar", através de trejeitos e posturas a partir do convívio com sua habilidade recém adquirida. Nick só se torna capaz de amar quando se permite atingir e ser influenciado pelo que ouve do universo feminino.

\section{Consumo enquanto referência para identidades de gênero}

As relações entre consumo e as identidades de gênero perpassam toda a narrativa que se desenrola, em grande parte, em uma agência publicitária - local de trabalho do protagonista - a qual tem entre seus principais clientes marcas de produtos voltados prioritariamente para o público masculino. Desde que Nick entra no cenário da empresa onde trabalha e até a reunião com seu chefe na qual espera ser promovido, são citadas três marcas famosas de produtos tipicamente direcionados para o público masculino: uma marca de cerveja (Miller), uma de lâminas para barbear (Gillette) e outra de uísque. A associação com os consumidores de sexo masculino é evidente até pelo caráter das campanhas publicitárias, especialmente das marcas de cerveja que, ainda hoje, exploram a sensualidade do corpo feminino, o que o filme trata com menções à equipe sueca de biquíni. ${ }^{5}$ Com essas referências, a associação de Nick ao universo de consumo masculino é facilitada; recorrendo a algo que o filme sequer precisa construir: a menção a essas grandes marcas e a figuras como as suecas de biquíni é suficiente para comunicar seu público com o tipo de anúncio publicitário que Nick está habituado a criar.

Então, o filme explora a relação de familiaridade do público com grandes marcas, o que indica um sentido especial das relações de consumo nas sociedades contemporâneas por seu aspecto simbólico não somente do ponto de vista de estratificação e distinção à luz da perspectiva bourdieusiana (BOURDIEU, 2006), mas enquanto elementos da linguagem cotidiana que se tornam símbolos de identidade, frases de efeito, jargões e imagens que significam experiências e emoções e se tornam

5 Swedish Bikini Team: Grupo de modelos loiras que protagonizava os comerciais da cerveja Old Milwaukee nos anos 1980 e 90. 
parte do vocabulário e do inventário simbólico dos espectadores. Com isso, estabelecese uma comunicação quase direta, muitas vezes dispensando discursos explicativos: supõe-se que a maior parte do público de sociedades consumidoras tanto do cinema quanto de várias marcas populares nos Estados Unidos já associe diretamente a marca Gillette a consumidores do sexo masculino, por exemplo.

Campbell observa que os hábitos de consumo, enquanto práticas culturais, visam muito além do caráter utilitário das mercadorias, ao adquirirem valor e reconhecimento como construções simbólicas de elementos da subjetividade dos consumidores:

[...] ao escolhermos e comprarmos os produtos que desejamos (não aqueles de que 'necessitamos'),estamos expondo diretamente nossos sentimentos - e, consequentemente, nos livrando de limitações inúteis - da mesma maneira básica que fazemos nos contextos terapêuticos elaborados de modo autoconsciente (CAMPBELL, 2006, p. 62).

Nesse sentido, construir noções de masculino e de feminino associando-as a marcas e campanhas publicitárias sintetiza estereótipos de ambos em um imaginário já bem compartilhado e reconhecido pelos espectadores e expressa a imersão de seus realizadores dentro dessa cultura de consumo, até o ponto em que se torna difícil distinguir noções e estereótipos de gênero contemporâneos sem recorrer prioritariamente a seus hábitos de consumo enquanto indicadores culturais. Isso se faz presente em outras produções, como a série Sex and the city, os filmes dela derivados e em outros como Os delírios de consumo de Becky Bloom (Confessions of a Shopaholic, 2009) ou O diabo veste Prada (The devil wears Prada, 2006).

As relações entre consumo, cultura e identidade se mostram aqui particularmente relevantes já que a narrativa se desenrola justamente no universo de criação de campanhas publicitárias, problematizando especificamente como atingir um público consumidor feminino apresentado no filme como crescente. Ao inserir a questão "o que as mulheres querem" nesse cenário de publicidade e propaganda - ou seja, de estímulo ao consumo - e se considerar a importância dos hábitos de consumo para as identidades e para a vida emocional na modernidade, pode-se entender que o filme busca comunicação com as mulheres em um contexto no qual sua noção de autoidentidade já se revela mais individualizada. A construção do feminino que o filme faz Cad. de Pesq. Interdisc. em Ci-s. Hum-s., Florianópolis, Santa Catarina, ISSN 1984-8951 v.15, n.106, p. 59-90 - jan./jun. 2014 
insere-se então num contexto em que o poder de consumo é, de maneira geral, reconhecido como importante instrumento de afirmação da própria individualidade:

um comercial de TV mostra uma multidão de mulheres com uma variedade de penteados e cores de cabelos, enquanto o narrador comenta: "Todas únicas; todas individuais; todas escolhem X" (X sendo a marca anunciada de condicionador). $O$ utensílio produzido em massa é a ferramenta da variedade individual. A identidade - "única" e "individual" - que só pode ser encontrada quando se compra. Ganha-se a independência rendendo-se. [...] A medida em que essa liberdade fundada na escolha do consumidor, especialmente a liberdade de auto-identificação pelo uso de objetos produzidos e comercializados em massa, é genuína ou putativa é uma questão aberta. Essa liberdade não funciona sem dispositivos e substâncias disponíveis no mercado (BAUMAN, 2001, p. 98).

É nesse contexto cultural em que identidade, consumo e sexualidade são tratados como praticamente indissociáveis e interdependentes que o cenário do filme no universo da publicidade se torna mais significativo. Aqui, as palavras de Dan para Nick, ao falar dos tempos áureos de sua empresa nos anos 1980, servem também para contextualizar os espectadores:

...nos anos 1990, homens simplesmente pararam de dominar como os dólares eram gastos e perdemos nosso compasso. Mulheres entre 16 e 24 é o grupo de consumidores que cresce mais rápido. $\mathrm{E}$ estamos falando de garotas que nasceram no meio dos anos 1980. Eu me enganei. Enquanto estávamos ganhando fazendo comerciais de cerveja com suecas de biquíni, a indústria vinha se transformando. Nós éramos A agência na cidade. Agora estamos lutando pelo terceiro lugar. Se não evoluirmos e pensarmos para além de nossa habilidade natural, a gente vai afundar.

Se por um lado, apostam no dom "natural" de Darcy enquanto mulher para reerguer a companhia, por outro, a escolha não deixa de ser pragmática, com a questão da competitividade da companhia sendo enfatizada. Não se propõe com a contratação de Darcy nenhuma grande mudança de postura na empresa; trata-se, apenas, de colocar no cargo uma especialista em anúncios para mulheres por ser mulher, já que sua participação no mercado na condição de consumidoras, de acordo com o filme, crescera significativamente. O perfil profissional de Darcy, contudo não é apresentado na chave de estereótipos femininos de suavidade e delicadeza, o que se entende pela referência masculina que é feita a ela como "Darth Vader" dos anúncios publicitários. O filme desconstrói essa imagem pelos pensamentos que Nick ouve dela e pelo envolvimento emocional que os dois estabelecem, mas reforçando - inclusive com

Cad. de Pesq. Interdisc. em Ci-s. Hum-s., Florianópolis, Santa Catarina, ISSN 1984-8951 v.15, n.106, p. $59-90$ - jan./jun. 2014 
a demissão de Darcy - a ideia de que o mundo dos negócios ainda é regido por valores culturalmente associados à masculinidade, como a agressividade e o ímpeto competitivo.

No primeiro contato de Nick com Darcy, bem na hora em que ela entra na sala, ele deixa seu lápis cair e, enquanto ela é cercada de pessoas que a cumprimentam e obstruem a visão de Nick, ele engatinha no chão, ao mesmo tempo procurando seu lápis e tentando vê-la. Ele está de quatro, quando ela se aproxima, pegando o lápis que ele deixara cair e entregando-lhe, enquanto se apresenta simpaticamente. Essa disposição dos corpos em cena, somada ao acanhamento que Nick demonstra nesse contato, expressa, metaforicamente, tanto a diferença hierárquica ali presente quanto o desconforto de Nick nessa posição que sugere subjugação. Diferentemente de outras situações que poderiam ser consideradas "românticas", ele não está aos pés dela para uma proposta de casamento ou declaração de amor. Outra impressão sugerida nessa situação é de que Nick só está aos pés de Darcy "por acaso", seja, literalmente, porque deixou seu lápis cair, seja metaforicamente, apenas por que seu chefe a contratara de repente por ser uma mulher que aparentava ter potencial para o cargo e acabara de sair da empresa onde estava. De maneira que Nick não reconhece essa diferença hierárquica entre eles.

Após a reunião, na qual Darcy distribui uma caixa rosa com produtos femininos que estariam em busca de novas campanhas publicitárias, há um corte para Nick assistindo um jogo de basquete pela televisão e bebendo vinho. Desapontado com o resultado do jogo, ele muda de canal. Está passando uma cena de Caçada ao Outubro Vermelho (The hunt for Red October, 1990), em que o capitão do submarino, interpretado por Sean Connery, com sotaque carregado, fala seriamente do perigoso jogo em que se encontra, enquanto Nick faz piada com seu sotaque. Ele muda de canal e cai em um programa de receitas. Com expressão de aversão, muda novamente, dessa vez para um telejornal falando de mulheres e política. Ele franze o cenho e muda mais uma vez, caindo em um programa de ginástica, em que uma instrutora com belo corpo e roupa justa mostra um exercício para glúteos. Nick se retém um pouco nesse canal apenas para apreciar as nádegas definidas da instrutora. Logo ele muda de canal 
mais uma vez, vê um homem terminando um número de ginástica olímpica e um narrador anuncia: "vamos ver agora a final feminina".

O uso das imagens televisivas também contribui para a construção e desconstrução da masculinidade de Nick, seja por seu inicial interesse pela partida de basquete, pelo filme com Sean Connery ou pelos glúteos da instrutora de ginástica, seja por sua aversão ao programa de receitas, às notícias sobre mulheres na política ou a final feminina de ginástica. Sean Connery pode também ser considerado um ícone cinematográfico de masculinidade, enquanto ator que se consagrara no papel do espião 007, que, entre outras características, é considerado símbolo de charme masculino, além de sempre conquistar belas mulheres. Mais adiante, depois que Nick já se habituara a ouvir os pensamentos das mulheres, é apresentada sequência semelhante, mas com uma inversão, na qual o interesse de Nick por programas construídos como caracteristicamente "femininos" se mostra preponderante em relação a esses que agora o filme constrói como "masculinos".

Nick exclama: "Há estrógeno demais na televisão hoje em dia". Com os dentes, ele tira a rolha da garrafa de vinho, enche sua taça até a metade, e, levantando-se desajeitadamente, continua seu raciocínio: "E todos sabemos que o antídoto perfeito para estrógeno é Frank." Em seguida, ele coloca uma música de Frank Sinatra - I won't dance - e faz um pequeno número de dança, vestindo um chapéu, de maneira que parece homenagear Fred Astaire. A maior parte da trilha sonora do filme é composta por canções de jazz, algumas consagradas na voz de Frank Sinatra. Pela alusão que Nick faz ao cantor, tem-se a imagem dele como símbolo de masculinidade, certamente por seu sucesso com o público feminino.

Convém observar que Sinatra consagrara-se como grande intérprete principalmente na década 1950, sendo que os anos 1960 dariam lugar a ícones como Elvis Presley e Beatles, que, na época do ainda jovem rock'n roll, remetiam à rebeldia e protesto. De maneira que Sinatra não seria apenas símbolo de masculinidade, mas uma masculinidade específica pré-revolução sexual, pré-liberação feminina. Nesse sentido, sua presença no filme é ainda mais significativa, especialmente em um dos primeiros momentos em que Nick demonstra sentir alguma afeição por Darcy, quando ela está trabalhando no escritório à noite, descontraidamente, ao som de Frank Sinatra. 
O gosto de Darcy por Sinatra não apenas contribui para constituir alguma afinidade com Nick como também para apresentá-la, a despeito da imagem de profissional temida e combativa, como uma mulher que aprecia o charme daquele que o filme apresenta como um símbolo de masculinidade "à moda antiga".

A utilização da música para caracterização das personagens e noções de masculino e feminino é reiterada quando Nick resolve começar a experimentar os produtos da caixa rosa buscando alguma inspiração para campanhas para aqueles produtos. Ele começa com um batom, mas o máximo que consegue imaginar é um cenário com uma mulher seminua sob uma cachoeira. Então ele decide que precisa mudar de música, pois, dentro do que se entende, Frank Sinatra seria masculino demais para o momento em que ele está tentando pensar como uma mulher. Vendo a mochila de sua filha jogada na sala, ele a vasculha e encontra entre seus CDs o disco de Meredith Brooks, que escolhe apenas por achar a mulher da capa atraente. Há um pequeno e hilário clipe, ao som da canção Bitch, ${ }^{6}$ em que Nick experimenta itens como maquiagem, cera para depilação e esmalte.

Nick é flagrado por sua filha e seu namorado dançando de meia calça e com maquiagem ao som do $C D$ da garota. $O$ rapaz então se retira e a garota tem uma discussão com seu pai, enfatizando que ele é incapaz de ouvi-la, o que serve como antecipação do que ocorrerá no filme, uma vez que logo em seguida ele sofre o acidente a partir do qual escuta os pensamentos das mulheres. De início, a habilidade recém-adquirida por Nick, além de assustá-lo, incomoda-o profundamente, especialmente quando ele percebe no ambiente de trabalho que praticamente todas as mulheres por quem passa nutrem algum pensamento hostil em relação a ele. Nick se choca com os pensamentos nada lisonjeiros que ouve a seu respeito no trabalho; desde o da mulher para quem sugerira não comer doces, até Darcy, que interpreta seu atraso na primeira reunião como uma tentativa de demonstração de poder.

\footnotetext{
${ }^{6}$ A letra, muito pertinente à construção do feminino no filme, sugere um caráter plural da identidade do eu lírico, em versos como: "sou um pouquinho de tudo/embrulhado em uma só/Sou uma puta, sou uma amante/Sou uma criança, sou uma mãe/Sou uma pecadora, sou uma santa/Sou seu inferno, sou seu sonho/ Não sou meio termo/ Você sabe que não iria querer de outro jeito".
} 


\section{Mudanças e reminiscências: amor, sexo e afetividade após "ouvir as mulheres"}

É significativo que o "dom" adquirido por Nick seja tão incômodo por, efetivamente, pela primeira vez, ele se encontrar em uma situação em que se importa com o que as mulheres estão pensando a seu respeito. "Não se importar" faz parte da construção imaginária de homens de sucesso e conquistadores, denunciando, mais especificamente, uma ignorância mais ou menos intencional e que agora se torna impossível. Tanto que seu primeiro impulso é de tentar reverter a aparente "maldição" repetindo os passos da noite em que sofrera o acidente e é eletrocutado. A tentativa fracassa e desesperado, ele procura a terapeuta de casais que o atendeu pouco antes de seu divórcio. A terapeuta se mostra cética, mas acaba convencida quando ele "advinha" sua idade. Ele revela seu desespero para ela, que toda mulher que ele ouve o considera um canalha, mas ela o convence de que aquilo é um dom:

Freud morreu aos 83 anos ainda se perguntando uma questão: ' $O$ que as mulheres querem?' Não seria estranho e maravilhoso se você fosse o único homem na terra finalmente capaz de responder essa questão? Algo extraordinário e milagroso aconteceu com você. Meu conselho é: você deve aprender com isso. Não há uma única mulher que eu trate que não queira que seu homem a entenda melhor. Se homens são de Marte e mulheres são de Vênus, ${ }^{7}$ você fala venusiano! O mundo pode ser seu!

Convém observar a mudança de perspectiva em função da insinuação de um ganho de poder com a expressão: "o mundo pode ser seu". Pelo menos, nesse momento, a questão da dominação masculina parece estranhamente incentivada pela psicóloga que, como o filme sugere em seus pensamentos, é apenas mais uma mulher que reprova Nick por suas posturas machistas. Nick aprecia muito a ideia de poder explorar aquela habilidade em benefício próprio e começa marcando um encontro com Lola. Ouvindo os pensamentos da moça, ele trabalha seus discursos de maneira a dizer exatamente aquilo que percebe que ela gostaria de ouvir e consegue marcar um encontro com ela já naquela noite.

\footnotetext{
7 Referência ao best-seller, nos anos 1990 de: GRAY, J. Homens são de marte, mulheres são de Vênus. Rio de Janeiro: Rocco, 1996.
} 
Há duas questões importantes expressas no encontro entre Lola e Nick. A primeira é a maneira diferenciada com que é construída e aludida a relação sexual quando essa se dá com uma mulher que não é aquela apresentada como o par romântico. As cenas do encontro com Lola são construídas de maneira a reforçar seu caráter especificamente sexual e não the conferem, dentro da linguagem cinematográfica explorada, qualquer expectativa mais romântica, a começar pela ambientação: há um plano de um trem urbano passando de noite sobre uma ponte, a câmera percorre o cenário sujo e parcamente iluminado, ao som de um jazz intenso em saxofone que remete a músicas de boate de strip-tease, enquanto os dois se beijam contra uma parede. Isso remete a toda análise que Gorbman empreende da construção de sentidos a partir das melodias empregadas no cinema, onde ela observa que "a sedutora é frequentemente acompanhada de um clarinete ou saxofone de cocktaillounge jazz" (GORBMAN, 1987, p. 83). Lola convida Nick para seu apartamento, receosa de ser julgada como uma vadia ou como alguém que estará sempre à disposição dele. Ao dizer a ela que ele pode esperar para subir a seu apartamento e ela não precisa levá-lo se não se sentir pronta, a moça se empolga, beijando-o com vontade e a cena seguinte já mostra os dois na cama. O jazz sensual dos beijos dá lugar a uma música latina animada, cujo ritmo dá mais um tom de comicidade à cena do que de erotismo.

Não são utilizadas canções lentas ou delicadas, os cenários - tanto externo quanto interno da casa de Lola - não são construídos na chave da beleza ou tentativa de aproximação afetiva; o lugar onde se beijam parece sujo e perigoso, o apartamento parece incomodamente apertado e cheio de tralhas, além de tremer a cada passagem do metrô. Não se enfatiza, nem no cenário, nem nas personagens, nem na música, qualquer forma de apreciação estética, em geral presente em cenas "de amor". O próprio ritmo da cena e da sequência dos eventos é mais acelerado do que de cenas românticas como a de Jack e Rose no carro no compartimento de carga do Titanic (Titanic, 1997). Mesmo naquele cenário que, a princípio, não seria considerado romântico, são captados ângulos do automóvel e do casal que conferem beleza plástica à cena, além da trilha sonora que colabora para edificar aquele momento como consumação do amor de Jack e Rose. Aqui, por outro lado, a rudeza do cenário é 
intencionalmente destacada, a cadência da música não sugere doçura, as personagens não trocam carícias ou sinais de ternura, apenas se atracam de forma quase animalesca. Por todo esse conjunto, somando-se as piadas com os pensamentos de Lola e o nervosismo de Nick ao ouvi-los, tem-se claramente construída uma sequência para comunicar um ato sexual que, enquanto fim em si mesmo, não proporcione empatia, seja entre o casal ou para os espectadores.

Quando apaixonado por Darcy, Nick age de forma diferente: num momento em que essa se questiona mentalmente se o convida ou não para ir a seu apartamento, Nick não se aproveita da oportunidade, mas corta o pensamento dela desejando boa noite. É certo que o filme em momento algum constrói Lola como interesse romântico, apenas como potencial conquista sexual. De qualquer forma, ainda chama atenção que, ainda tão recentemente, Hollywood ainda encontre sucesso explorando com todo seu aparato expressivo - cenários, música, iluminação, ângulos e movimentos de câmera - essa separação moral entre sexo e amor em mais um filme em que o contato sexual entre o par central parece censurado até como conceito.

A segunda questão se refere à importância da performance sexual em seus aspectos mais técnicos e quase mecânicos, com função de proporcionar o máximo de prazer para o outro e, para si, um reconhecimento, uma reafirmação da própria identidade sexual, das próprias capacidades e uma avaliação favorável do próprio desempenho.

\footnotetext{
Todas as formas de relacionamento íntimo atualmente em voga portam a mesma máscara de falsa felicidade que foi usada pelo amor conjugal e mais tarde pelo amor livre [...] Ao olharmos mais de perto e afastarmos a máscara, descobrimos anseios não realizados, nervos em frangalhos, amores frustrados, sofrimentos, medos, solidão, hipocrisia, egoísmo e compulsão à repetição [...]. As performances substituíram o êxtase, o físico está por dentro, a metafísica, por fora [...]. A abstinência, a monogamia e a promiscuidade estão todas igualmente distantes da livre vida da sensualidade que nenhum de nós conhece (SIGUSH apud BAUMAN, 2004, p. 64).
}

A questão da performance é comicamente explorada nessa relação, sendo que Nick, ouvindo os pensamentos dela durante as preliminares fica cada vez mais incomodado; desde a referência ao beijo de língua exagerado ao desapontamento da moça com o tamanho de seu pênis, operando toda uma desconstrução da imagem segura que Nick tinha de si como parceiro sexual antes de se importar com o que as Cad. de Pesq. Interdisc. em Ci-s. Hum-s., Florianópolis, Santa Catarina, ISSN 1984-8951 v.15, n.106, p. 59-90 - jan./jun. 2014 
mulheres querem. Por trás da irreverência da cena, que se sustenta sobre a capacidade de ouvir e saber do desinteresse da moça no ato, há um tema que se tornou recorrentemente discutido em revistas, jornais e manuais de autoajuda: o prazer feminino, como atingi-lo e o papel do homem nesse processo. Além de signo da liberação sexual, o orgasmo feminino tornou-se fator preponderante na qualificação da conquista sexual masculina contemporânea, funcionando também como fonte de ansiedades.

Hoje em dia, as mulheres deixaram cair muitas de suas reservas sexuais. Aos olhos dos homens, isto as torna mais acessíveis como parceiras sexuais, porém, também mais ameaçadoras. [...] O "desempenho" sexual torna-se, assim, uma outra arma na guerra entre homens e mulheres; as inibições sociais não mais impedem as mulheres de explorar a vantagem tática que a atual obsessão pelas medidas sexuais Ihes deu (LASCH, 1983, p. 236).

Um efeito disso, já observado por Bauman (2004), é a valorização da prática sexual não tanto pelo prazer mais espontâneo que esta propiciaria, mas pelo domínio de seus aspectos mais técnicos, visando à maximização objetiva e racionalizada do prazer, promessa de orgasmos múltiplos cujas fórmulas são facilmente encontradas em bancas de jornal, seja em sessões de revistas femininas ou livros baratos de autoajuda. A vida sexual passa a ser cada vez menos percebida como espaço de espontaneidade e libertação; ela parece mais distante de um estado idealizado de natureza perdida, enquanto fuga socialmente aprovada de constrições e recalques sociais, para ser inserida numa dramaturgia com papéis mais ou menos definidos: relacionar-se sexualmente é encenar um papel, dentro de interditos e liberdades definidos culturalmente e/ou interpessoalmente, com exigências e expectativas - normalmente elevadas - determinadas por "scripts sexuais" (GAGNON apud BOZON, 2004, p. 129).

$\mathrm{Na}$ medida em que permitem identificar, interpretar e estabilizar os componentes sexuais da vida sexual, os scripts sexuais têm uma função estruturante para o imaginário sexual dos grupos, para os relacionamentos e para os indivíduos. Essa estruturação não se limita às dicotomias que oporiam o apropriado ao inapropriado em matéria de sexualidade, ainda que ela os englobe: a estruturação através dos scripts tem como principal efeito inscrever a sexualidade em uma dramaturgia (BOZON, 2004, p.132, grifo nosso). 
Aparentemente, o aspecto da dramaturgia é incrementado no atual contexto de ampla presença de mídias audiovisuais, de forma que já não basta cumprir os scripts, as encenações, bem como o cuidado do corpo e os resultados esperados devem se aproximar cada vez mais de performances dignas de um prêmio Oscar, ou, pelo menos, de uma avaliação positiva e não muito complacente dos críticos, reforçando o sentimento caracteristicamente narcísico das sociedades contemporâneas de ânsia por aprovação e reconhecimento.

Apesar das dificuldades, Nick consegue proporcionar à Lola uma relação extremamente prazerosa, deixando sua parceira extasiada, embora ele mesmo não pareça tão empolgado. Muito ofegante, sua expressão mais denota exaustão e alívio do que prazer. Alguma satisfação só se esboça no rosto de Nick após ele ouvir Lola pensar nele como "um deus do sexo". Apenas após a confirmação de seu bom desempenho é que ele parece se sentir bem. Isso não só é expressão patente da importância do desempenho que vem se discutindo, como também de sua importância para a autoidentidade que, mesmo no âmbito mais íntimo e pessoal, requer aprovação e reconhecimento de um terceiro, incorrendo no que Lasch (1983, p. 30) já observara: "[...] o narcisista depende de outros para validar sua autoestima. Ele não consegue viver sem uma audiência que o admire".

Isso reforça a idealização do sexo com amor, que se torna último refúgio idealizado de uma expressão absolutamente "natural" e "espontânea" do indivíduo. A relação entre Nick e Lola cumpre dentro do filme uma função exemplar de que uma prática sexual tecnicamente impecável e eficiente ao responder a proposta de gerar prazer e reconhecimento no parceiro revela-se banal, vazia e, até mesmo desprazerosa. O filme reitera a importância do sexo com amor, como é típico em Hollywood, pela sua não ocorrência. Seja no discurso da filha de Nick, que já crê saber tudo que precisa sobre sexo, que só se deve perder a virgindade com alguém por quem se esteja apaixonado, seja na maneira completamente diferente com que Nick lidará com Darcy nessa questão, abrindo mão da possibilidade de ir para a cama com ela depois do primeiro encontro. Isso revelará um caráter romântico recém-descoberto dos sentimentos de Nick por Darcy. 
[...] o amor romântico suscita a questão da intimidade. Ela é incompatível com a luxúria, não tanto porque o ser amado é idealizado - embora esta seja parte da história -, mas porque presume uma comunicação psíquica, um encontro de almas que tem um caráter reparador. $O$ outro, seja quem for, preenche um vazio que o indivíduo sequer necessariamente reconhece - até que a relação de amor seja iniciada. E este vazio tem diretamente a ver com a autoidentidade: em certo sentido, o indivíduo fragmentado torna-se inteiro (GIDDENS, 1992, p. 56).

Assim, o sexo como amor, na construção fílmica, permanece ao mesmo tempo como sagrado, intocado e imaginário. Sua ocorrência não é sugerida em momento algum do filme. Isso apenas contribui, especialmente no caso do sexo feminino, para reiterar um condicionamento cultural da satisfação sexual feminina à experiência amorosa principalmente idealizada, expressando que a busca do prazer, especialmente para o público feminino, é construída de forma desfavorável, como comportamento censurável. Nisso, reproduz-se toda uma série de "normas emocionais" que "em geral, são indicadas por afirmações contendo termos como 'deveria', 'precisa', ou 'tem direito a' em referência a sentimentos ou quadros de sentimentos" (THOITS, 1991, p. 181). E, como se observa, essas normas tendem a ser muito diferentes para homens e mulheres.

O valor das mulheres corresponde à parcimônia com que elas se entregam, o dos homens ao número de "objetos" conquistados: a oposição raridade/número transformou-se em uma estrutura psicológica profundamente interiorizada, conforme indica a divergência das respostas às perguntas sobre o número de parceiros sexuais. Por conseguinte, o duplo padrão de sexo, gerador de injunções contraditórias para os indivíduos, tanto homens quanto mulheres, não desapareceu. [...] Os homens continuam a ser considerados os principais agentes do ato sexual, e o desejo sexual feminino continua a ser amplamente ignorado, como se o lugar [das mulheres] devesse permanecer limitado à afetividade (BOZON, 2004, p.95).

Após a relação com Lola, a sequência seguinte é uma espécie de videoclipe ao som de um jazz animado, alternando imagens em que se entende que Nick está utilizando sua habilidade, ao mesmo tempo, para explorar os pensamentos das mulheres e para aproveitar as ideias de Darcy. Veem-se cenas de Nick próximo a mulheres, às vezes esticando seu pescoço como que num esforço de tentar ouvi-las melhor, frequentemente esboçando expressões faciais de satisfação. Nick aparece em alguns locais e atividades tipicamente associados a mulheres, como uma aula de ioga 
ou um salão de cabelereiro. Ao som da mesma música, aparecem algumas cenas com Darcy em que se entende que ele vem obtendo sucesso em aproveitar os pensamentos que ouve dela. Essa sequência musical basta para a construção do sucesso de Nick usando sua habilidade, mantendo seu objetivo principal: desbancar Darcy do cargo para o qual ela fora contratada.

Entretanto, a cena seguinte sugere um ganho de afeição e alguma mudança: Nick aparece conversando na cantina com suas colegas de trabalho, contando piadas sobre homens que ouvira no salão e dando conselhos sobre relacionamentos. Ele parece se divertir naquela conversa com as mulheres e se envolver em suas vidas pessoais ao ouvi-las e oferecer palavras amigas. É um salto significativo ao se considerar que, de início, havia uma recusa em ouvir os pensamentos femininos, recusa da qual se passou à utilização pragmática dessa habilidade no emprego especialmente para roubar ideias de Darcy - e que agora parece ser algo partilhado com simpatia gosto e "naturalidade". Há um contraponto importante em relação à sequência anterior: nos locais em que ele é mostrado frequentando durante a música, só se vê figurantes que correspondem a estereótipos de beleza feminina típicos de modelos de capa de revista e campanhas publicitárias - jovens de corpos esguios cuidando de sua beleza nos salões e de seu corpo praticando esportes ou ioga, em outras palavras, cuidando prioritariamente do físico e de sua apresentação estética. Isso, associado à canção e às expressões faciais maliciosas de Nick, implica um interesse pelas mulheres ainda definido prioritariamente por seu desejo sexual, embora os locais onde ele estivesse não restritos a mulheres aqui construídas como bonitas e sensuais. Já no trabalho, ele se diverte e se envolve em assuntos da vida pessoal de mulheres que não correspondem a esses padrões de beleza midiáticos. E, pela descontração de Nick que a cena sugere, entende-se que ele já não está usando sua habilidade no momento com qualquer finalidade de conquista sexual ou profissional, indicando um ganho de afeição pelas mulheres e por seu universo, funcionando como marcador de uma mudança relevante na narrativa e na constituição da personagem.

Em momento um momento mais adiante, quando Nick trabalha com Darcy ouvindo suas ideias de um anúncio para a Nike, já não é claro se eles tiveram uma ideia juntos ou se ele simplesmente pegou uma ideia de Darcy e a transformou. É a 
partir daí também que o filme mostra um ganho recíproco de afeto entre os dois; em que falam dos boatos que um ouvira do outro antes de se conhecerem, em que Nick ouve o pensamento angustiado de Darcy por ser considerada a "Darth Vader devoradora de homens do mundo da publicidade" e, de maneira complacente, diz que não a vê daquele jeito. E, o que é mais significativo de toda essa sequência com Darcy no escritório: Nick ouve Darcy repetir para si mesma em pensamento: "não se apaixone por um cara do trabalho". A música no momento é singela, lenta, com notas doces de piano e a reação de Nick a esse pensamento não sugere malícia ou oportunismo para se aproveitar dessa "fraqueza" que ele detecta em Darcy. Ao contrário, a reação dele é perguntar: "por quê?", com uma expressão e um tom de voz que mais se aproximam de condolência.

Entende-se então que Nick já sofrera uma transformação relevante a partir de sua habilidade e que esta já afetou a maneira como ele se relaciona com as mulheres, expressando um ganho de sensibilidade, também visível na relação com sua filha. Há uma sequência em que os dois fazem compras juntos, numa estrutura semelhante ao banho de loja de Vivian em "Uma linda Mulher", ao som da canção What a girl wants, na qual Alex experimenta vários vestidos e seu pai opina sobre eles. Vê-se que os dois discordam quase o tempo todo, mas parecem se divertir, brincando e até dançando, apesar de uma expressão facial de embaraço por parte da garota.

Hollywood frequentemente apresenta o "ir às compras" como algo alegre, reforçado pela trilha sonora. Tais cenas dificilmente têm um homem como personagem central, este aparece normalmente como coadjuvante no que os filmes parecem construir e reiterar como local de diversão feminina por excelência. $O$ homem, não raramente, quando apresentado nessa situação, é construído como estranho, deslocado, como Nick é mostrado nas discordâncias com sua filha, em suas expressões de tédio perguntando o preço dos vestidos ou dançando histrionicamente com ela. É ainda mais significativa que a cena em questão se passe com uma adolescente, considerando essa fase como decisiva na construção de identidade individual enquanto momento de transição para a vida adulta repleta de ritos de passagem, o que, no caso da filha de Nick, é simbolizado pelo baile e pela perda da virgindade.

Cad. de Pesq. Interdisc. em Ci-s. Hum-s., Florianópolis, Santa Catarina, ISSN 1984-8951 v.15, n.106, p. 59-90 - jan./jun. 2014 
Nos filmes em que se vê esse tipo de construção divertida de um momento de compras, nota-se um expressivo marco de transformação da identidade, como acontece em "Uma Linda Mulher". Embora não seja necessariamente apresentado como central no filme, percebe-se explícita uma relação quase indissociável entre consumo, identidade e afetividade, no que a compra do vestido certo, dos acessórios certos é diferencial - ou crê-se que seja - na conquista do amado.

O consumo interpela as qualidades alienadas da vida social moderna e se apresenta como a solução: promete as coisas mesmas que o narcisista deseja - charme, beleza e popularidade - através do consumo dos tipos "certos" de bens e serviços. Daí que todos nós, nas condições sociais modernas, vivemos como que cercados de espelhos; neles procuramos a aparência de um eu socialmente valorizado, imaculado (GIDDENS, 2002, p. 160).

Quando a busca amorosa e o consumo se fundem no cinema, coloca-se em evidência uma relação na qual os objetos de consumo assumem caráter de instrumentos fundamentais enquanto símbolos reconhecidos da própria subjetividade. Isso tende a ser explorado, na maioria das vezes, em sequências de compra de roupas, no que o figurino dá visualidade a um tipo de pessoa, mas cuja aparência só é legitimada quando essa figura vestida, produzida e maquiada encontra o reconhecimento "espiritual" por meio da conquista amorosa. A roupa então dá a forma, e o amor dá o conteúdo.

Apesar da aproximação entre pai e filha sugerida nessa sequência, o diálogo que se sucede encerra tal ideia. Nick tenta conversar com a garota sobre sexo e preveni-la de eventuais más intenções de seu namorado, mas ela não apenas dispensa a conversa, dizendo saber tudo o que precisa, como também critica o comportamento recente do pai, tentando se aproximar dela depois de anos ausente. É ainda mais contundente o pensamento que Nick ouve da garota: "você nunca teve um relacionamento de verdade com ninguém em sua vida inteira”. É logo depois dessa cena, em que o filme mostra a mudança de Nick vendo televisão, sensibilizando-se com o discurso de uma mulher obesa em um programa de auditório que "só queria ser uma boa mãe". Não só o quadro da mãe obesa comove Nick, como também a conclusão de uma receita de bolo de casamento que se encerra com uma mensagem que tem um aspecto metafórico bem claro: "agora que você viu como o bolo é montado, quando vir 
um bolo de casamento, poderá apreciar sua arquitetura interna, bem como seu exterior". O interesse de Nick, seja pela arquitetura de um casamento metaforicamente representada, seja pelo depoimento de uma mãe, aparecendo logo após a conversa com sua filha, coroa sua aproximação de símbolos construídos como tipicamente femininos por meio de construções que associam a mulher não apenas à sensibilidade e emotividade - expressas no choro que Nick inicia frente à TV - mas à maternidade e seu papel fundamental tanto para a família quanto para ideais socialmente cultivados na modernidade de papéis femininos.

A idealização da mãe foi parte integrante da moderna construção da maternidade, e sem dúvida alimentou diretamente alguns dos valores propagados sobre o amor romântico. A imagem da 'esposa e mãe' reforçou um modelo de 'dois sexos' das atividades e dos sentimentos [...]. O elemento distintamente novo, aqui, era a associação da maternidade com a feminilidade, como sendo qualidades da personalidade - qualidades estas que certamente estavam impregnadas de concepções bastante firmes da sexualidade feminina (GIDDENS, 1992, p. 53).

Nesse sentido, outro aspecto marcante da transformação de Nick é que, depois da frustração de Alex em seu baile ele é quem dá suporte emocional à garota. A garota não procura seu pai depois da frustração no baile, mas sua mãe. Como parece haver algum problema na ligação, a mãe telefona para o celular dele e pergunta se ele sabe da filha, se ela não estaria no baile. Reforçando esse aspecto associado à maternidade, depois de buscar sua filha no baile e consolá-la, há uma cena em que a garota já se encontra em casa, dormindo em sua cama, parcialmente descoberta. Nick então se aproxima, cobre-a até o ombro, dá-lhe um beijo carinhoso e a olha com ternura antes de sair do quarto. As construções cinematográficas da figura do "pai amoroso", em muitos filmes hollywoodianos, como em "Sintonia de Amor", ou em "O amor não tira férias", encontram-se amparadas pelo fato do pai ser um viúvo ou outras em que a ausência materna é circunstancial ou inusitada. É admirável que, tão frequentemente, cenas que valorizem demonstração de sensibilidade e carinho do pai por seus filhos sejam construídas em função de alguma situação incomum e inesperada que os coloca na obrigação de exercer esse papel, como a perda da esposa, subentendendo-se que se preserva a ideia de que tal papel é "naturalmente" feminino e, para ser cumprido por um homem, necessita de algo que justifique a impossibilidade de uma mulher exercê-lo. 
A narrativa prossegue enfatizando uma trajetória de afetividade crescente de Nick, seja por sua filha, por suas colegas de trabalho ou, mais enfaticamente, por Darcy. Nesse sentido, mais próximo ao final, ele já demonstra arrependimento de ter se aproveitado de sua habilidade especial para roubar ideias de Darcy, como se expressa no seguinte diálogo com Morgan:

- Homens são mais estúpidos, é verdade.

- Para com isso!

- Mas eles são!

- O que você quer dizer com 'eles são'? Você é oficialmente uma mulher agora?

- Oh, eu gostaria! Uma mulher não teria ferrado a mulher que ela ama. Não, elas não pensam dessa maneira.

Três elementos são marcantes neste diálogo: o primeiro é que Nick já se sente tão profundamente próximo do feminino a ponto de se referir aos homens distintamente, na terceira pessoa. O segundo é que esta distinção tem um fundamento explicitamente moral, expresso na ideia de que uma mulher não teria feito o que ele fez. E, por último, é uma confissão de amor por Darcy. A personagem agora é oficialmente referida para o espectador como amada de Nick. Embora previsível, pelo ritmo da história, tal revelação é um tanto repentina. E, ao se revelar em uma conversa em que Nick se distingue tão expressivamente dos homens, torna-se ainda mais clara a associação que o filme reproduz entre o feminino e o amor romântico, sendo que Nick deve chegar ao ponto de distinguir-se dos homens para atingir sua capacidade de amar e considerar-se apaixonado, inserindo-se assim na "mística do príncipe encantado" (CHAUMIER, 1999, p. 170), mas no papel da mulher, que espera uma confirmação de sua identidade pelo encontro do amor.

Nick tenta revelar a Darcy seu segredo depois da reunião bem sucedida com executivos da Nike, mas Darcy, que parece já apaixonada por ele, deseja celebrar a conquista que ela entende ser principalmente dele. Ela então o convida para mostrar o apartamento que comprara recentemente e para o qual pretendia mudar-se em breve. A sequência no apartamento tem um conteúdo expressivo de romantismo ao mostrar Darcy compartilhando com Nick um importante projeto pessoal: o lugar destinado a ser seu lar. Embora não esteja necessariamente revelando para Nick planos nos quais o 
inclua, repartir tal tipo de projeto indica um envolvimento, uma espécie de convite para a narrativa pessoal que Darcy está a construir para si.

De acordo com Solomon (1994, p. 160),

apaixonar-se é quase inteiramente uma questão de olhar para frente, de vislumbrar o futuro, de se tornar mais do que de ser. Os dois ingredientes primários do apaixonar-se são, conformemente, fantasia e desejo. Ambos olham para frente e ambos envolvem o pródigo uso da imaginação.

De tal forma, essa cena se destaca pelas referências diretas a imaginar e projetar um futuro no apartamento ainda em reforma e sem móveis. O uso da imaginação é explorado na cena através dos diálogos, seja com ela descrevendo o que será cada cômodo, seja com Nick falando das festas que imagina na sala de jantar ou com eles dançando sobre a cama. Com isso, constrói-se uma partilha da intimidade tipicamente romântica cujo fundamento se encontra numa projeção mental deslocada do presente.

Diferentemente da cena com Lola, a intencionalidade de uma relação sexual aqui é bem mais sutil e alusiva. É curioso observar que, mais importante do que construir a ideia de que Nick e Darcy fizeram sexo naquela noite, numa sequência de cenas remetendo ao antes e depois do sexo, o filme registra e valoriza a fantasia compartilhada de dançar sobre a cama. Comunicar explicitamente se eles fizeram sexo naquele momento é menos relevante do que mostrá-los partilhando da fantasia sobre a cama inexistente. A cena seguinte não tem qualquer referência ao que se seguiria a uma noite de amor; nada de troca de carícias, despertar juntos ou despedida, o que deixa dúvidas se os dois teriam feito sexo na noite anterior. O que se segue ao fade out quebra o clima romântico ao mostrar uma tomada externa de prédios num dia chuvoso, sendo que a significação usualmente mais explorada de chuva nesse tipo de filme anuncia tristeza, luto ou problemas. O que se segue confirma essa indicação, com Nick entrando no escritório de Dan e recebendo a notícia de que Darcy fora demitida naquela mesma manhã. Nick insiste com seu chefe e acaba conseguindo convencê-lo de que Darcy fora responsável pelo sucesso da campanha e que ele deve ligar para ela e devolver-lhe o emprego. 


\section{0 desfecho da narrativa como um aprendizado moral}

No mesmo dia, Nick percebe uma pilha de pastas e se dá conta de que Erin, a estagiária que ele ouve ter pensamentos suicidas, não compareceu ao trabalho. Ele pergunta por ela para suas duas assistentes e essas revelam que a garota tentou marcar uma entrevista com Nick na época em que entrou na empresa, mas ele simplesmente pediu para que se livrassem dela. Somado ao sentimento de piedade que Nick desenvolvera por ela, há também remorso e ele sai em busca da garota, desesperado com a possibilidade de ela ter se matado. No bairro chinês, onde a garota moraria, uma velha senhora com ar misterioso lhe indica a direção do endereço que Nick procura, passando por um beco tenebroso. Um transformador estoura perto de Nick e faíscas voam para todos os lados, de forma semelhante ao momento do acidente após o qual ele adquirira a habilidade de ouvir pensamentos de mulheres. Desta vez, ele não sofre nenhum choque, mas a alusão das imagens aos primeiros instantes do filme sugere alguma mudança e logo em seguida, na casa de sua estagiária, Nick se dá conta de que não ouve mais os que as mulheres pensam. Não há mais chuva depois que ele sai do apartamento dela, indicando a proximidade de um desfecho feliz, especialmente depois que dois elementos construídos como de grande importância já se resolveram: Nick se livrara do seu dom - indicando, na mística hollywoodiana, que ele já aprendera sua lição - e conseguira ajudar uma pessoa em perigo e salvar uma vida.

Ele tenta insistentemente falar com Darcy, sem sucesso. É nesse período também que ele acaba por acudir sua filha após a frustração do baile de formatura. Sem conseguir dormir, ele retorna ao apartamento de Darcy e é recebido por ela à uma hora da manhã. Ela revela pensar em vender o apartamento já que não tem emprego para mantê-lo e Nick lhe conta que ela recuperara o emprego. Ele então confessa que a sabotou para conseguir seu cargo e que se aproveitara dela da pior maneira possível, o que a deixa sem palavras. Ele também revela seu crescente fascínio por ela e há um trecho particularmente significativo em sua declaração: "caras como o seu [ex]marido... ele fez você sentir que o preço que você paga por ser você é não ser amada. Não era isso que você estava tentando dizer na outra noite? Que você não era completa? Que 
não era realmente uma vencedora daquele jeito?" O uso do termo "vencedora" aqui é significativo em dois aspectos: o primeiro, como expressivo do ideal de self-made-man; o profissional de sucesso norte-americano que triunfa a partir do próprio esforço, persistência e valores.

A recompensa do trabalho e dos esforços é mais frequentemente o sucesso profissional; é a meta buscada pelo self-made-man ao longo de seu percurso de ascensão. Ele representa a realização de si acompanhada de provas materiais, mais frequentemente sob a forma de dinheiro (BIDAUD, 1994, p. 143).

O segundo e mais relevante: dentro dos termos que Nick coloca, especialmente se direcionando a uma mulher, fica patente que o ideal de vitória apresentado aqui, para que ela se sentisse "completa" e triunfante, requereria obrigatoriamente uma conquista amorosa convincente. Mais do que isso,

a lição de que se deveria apaixonar-se pela melhor pessoa possível mudou da nobre idealização do amante para a constante busca por algo melhor e o novo absurdo do "querer tudo" parece estar ditando o quanto o casamento - ou romance - é desejável, esperando dele um caminho para o sucesso social, em grande medida, da mesma maneira que jovens executivos ambiciosos vão ao trabalho esperando traçar seu caminho em direção ao topo da escada corporativa (SOLOMON, 1994, p. 339).

Se para o self-made-man, basta ser um profissional bem sucedido, com uma boa fonte de renda, como Nick vinha sendo, para a self-made-woman, ainda é necessário "ser amada" para se sentir completa. E o filme parece apresentar a ideia de que, no caso de uma mulher, o sucesso profissional e financeiro é praticamente incompatível com o sucesso amoroso. Não é surpresa que as duas coisas pareçam incongruentes, com tantos filmes apresentando como referência de amor ideal uma desvalorização moral do dinheiro, que aparece mais como empecilho para o romance do que como seu facilitador - embora ainda seja o dinheiro, nas sociedades capitalistas modernas, que ofereça condições de bancar a maior parte dos objetos de consumo e bens simbólicos de "romantismo" empregados durante o processo de sedução.

Ao fim de sua confissão, Nick, desajeitadamente, diz: "parece que eu estou bancando o herói aqui à uma da manhã, tentando salvar você, mas na verdade sou eu quem precisa ser salvo." Darcy não se pronuncia e Nick emenda que queria ser capaz de ler pensamentos naquele momento. Ela então responde que, se aquilo tudo é Cad. de Pesq. Interdisc. em Ci-s. Hum-s., Florianópolis, Santa Catarina, ISSN 1984-8951 
verdade e ela tem o emprego dela de volta, significa que ele está demitido. Ele se surpreende, mas admite ser algo merecido. Desconcertado, ele se dirige à porta, gaguejando que está sem graça de ter dito que precisava ser salvo. Há uma música melosa de piano, Darcy revela que não soube como reagir no começo e que cometera um erro. Nick então sobe as escadas em sua direção, empolgado, eles se aproximam e ela continua: "que tipo de cavaleiro em armadura brilhante seria eu se o homem que eu amo precisa ser resgatado e eu simplesmente o deixo ir embora por minha porta?" Nick suspira, troca de lugar com ela, sobrepondo-se de maneira que remete a uma pose bem característica de heróis de cinema quando acabam de resgatar suas donzelas, deixando ela se declinar suavemente em seus braços. Olhando para Darcy com um sorriso, ele diz: "meu herói" e há o beijo que encerra o filme.

\section{Considerações finais}

A ênfase numa inversão de papéis, no diálogo final, mais parece reforçar os estereótipos de gênero e os papéis românticos atribuídos ao masculino e ao feminino do que desconstruí-los. A mística do príncipe encantado é aludida pela imagem do cavaleiro em armadura brilhante, que deve salvar sua amada. Com essa troca de lugar, nenhuma mudança é realmente sugerida em termos de percepções do masculino e feminino nesse ideal romântico; a figura do cavaleiro é estritamente masculina e se mantém o pressuposto de que alguém precisa ser salvo, de que há uma personagem frágil e em perigo - simbolizada pela donzela - que é incapaz de salvar a si mesma. Não só se mantém uma imagem de dependência e subordinação - donzela em relação a cavaleiro - como se reproduzem os mesmos papéis de gênero, que são também complementares. Assim, entende-se que os componentes do imaginário moderno do amor, mesmo num filme dos anos 2000 com o título que anuncia "o que as mulheres querem", preservam um caráter essencialista na diferenciação de homens e mulheres. Embora Darcy, à primeira vista, pareça encarnar o papel de uma mulher forte, o filme desconstrói essa imagem o tempo todo, deixando essa força apenas nas referências que terceiros fazem a ela, mas nas quais ela sequer se reconhece. Ela lamenta ser vista como a chefe temida e, na cena em que ela e Nick se encontram no escritório de 
noite pela primeira vez, inclusive sua saúde se revela frágil em decorrência da grande pressão que sente em seu trabalho.

O mais sintomático, contudo, é que, da maneira como o filme constrói homens e mulheres, parece haver um ceticismo quanto à possibilidade de sensibilização masculina e sua consequente possibilidade de envolvimento emocional num relacionamento heterossexual. Lola chega a acreditar que Nick é gay, devido à sensibilidade e compreensão que ele demonstrara perante ela. $\mathrm{E}$ deixa isso mais claro ao enfatizar que, quando saíram, ele pensava como uma mulher, falava como uma mulher. Amar parece ainda ser considerado algo da natureza feminina, ainda que se trate de uma construção social e histórica. Nesse sentido, a tendência do ideal romântico de fusão, nos termos de Chaumier (1999), parece entrar em conflito com qualquer conquista de emancipação feminina, conflito este que se intensifica com a crença numa natureza feminina que aproxima a mulher do papel de esposa, orientada para a valorização da família, do lar e do abstrato universo das emoções. Grande parte do humor do filme se baseia nessas diferenciações culturalmente estabelecidas e que, embora se encontrem fortemente questionadas hoje, ainda se revelam presentes na formação mais íntima das identidades individuais.

Parece cada vez mais evidente que um dos problemas fundamentais da vida amorosa é o cultivo de ideais e princípios morais não raramente incongruentes, que justificam malabarismos sentimentais e psicológicos baseando-se em discursos que sugerem um esforço conciliatório pelo absurdo: a mulher deve fazer o papel de esposa e rainha do lar e ao mesmo tempo negá-lo, reafirmando-se em um cargo de sucesso. $\mathrm{O}$ homem deve sensibilizar-se, aprender a comunicar seus sentimentos e interpretá-los, mas sem deixar de dar mostras de virilidade dentro e fora do relacionamento, sob o risco de não ser considerado "homem o suficiente" e ser abandonado. Os discursos emancipatórios são incentivados, mas têm-se profunda dificuldade em abrir mão dos próprios valores que se exige transformar.

A vontade de conciliar os diferentes elementos em um único amor é sintomática da modernidade. O ideal é de concentrar toda experiência em uma única e só relação. A conquista deste ideal de autossuficiência constitui o ponto comum dos amores modernos (CHAUMIER, 1999, p. 38). 
A mensagem que o filme acaba retendo e reproduzindo então contribui para a manutenção de estereótipos de gênero que negam ao masculino a afetividade e sensibilidade e negam ao feminino a possibilidade de realização pessoal fora do campo de relações íntimas heterossexuais monogâmicas. Mas, possivelmente, o mais incômodo e expressivo desse filme é que tais perspectivas se veem tão consolidadas ao ponto de ser sugerido que um homem só possa desenvolver alguma inclinação afetiva por um passe de mágica que, muitas vezes, como o filme sugere, compromete sua masculinidade. Dessa forma, os aspectos de todo um processo histórico de socializações de masculino e feminino são tomados e reproduzidos como caracteres inerentes ao sexo, principalmente no que diz respeito às possibilidades de amar e constituir uma autoidentidade, a partir da experiência amorosa. 


\section{Referências}

BAUMAN, Z. Amor líquido: sobre a fragilidade dos laços humanos. Rio de Janeiro: Jorge Zahar, 2004.

. Modernidade líquida. Rio de Janeiro: Jorge Zahar, 2001.

BIDAUD, A-M. Hollywood et le rêve américain. Paris: Masson, 1994.

BOURDIEU, P. La domination masculine. Paris: Seuil, 1998.

A distinção: crítica social do julgamento. Porto Alegre: Zouk, 2006.

BOZON, M. Sociologia da sexualidade. Rio de Janeiro: Editora FGV, 2004.

CAMPBELL, C. A ética romântica e o espírito do consumismo moderno. Rio de Janeiro: Rocco, 2001.

. Eu compro, logo sei que existo: as bases metafísicas do consumo moderno. In: BARBOSA, L.; CAMPBELL, C. (Org.). Cultura, Consumo e Identidade. Rio de Janeiro: Editora FGV, 2006.

CHAUMIER, S. La déliaison amoureuse. Paris: Armand Colin, 1999.

CONNELL, R. W. Masculinities. Berkley: University of California, 1995.

GIDDENS, A. A Transformação da Intimidade. São Paulo: UNESP, 1992. Modernidade e Identidade. Rio de Janeiro: Jorge Zahar, 2002.

GORBMAN, C. Unheard melodies. London: BFI Publishing, 1987.

JARVIE, I. C. Sociología del cine. Madrid: Guadarrama, 1974.

LASCH, C. A cultura do narcisismo. Rio de Janeiro: Imago, 1983.

ROSSI, T. C. Projetando a Subjetividade: a construção social do amor a partir do cinema. 2013. 326 folhas. Tese (Doutorado em Sociologia) - Faculdade de Filosofia, Letras e Ciências Humanas, Universidade de São Paulo, 2013.

SOLOMON, R. About love - reinventing romance for our times. Lanham: Rowman \& Littlefield, 1994.

SORLIN, P. Sociologie du cinéma. Paris: Aubier Montaigne, 1982. 
THOITS, P. Emotional Deviance. In: KEMPER, T. D. (Org.). Research Agendas in the Sociology of Emotions. Albany: State University of New York Press, 1991.

Artigo:

Recebido em: 18/01/2014

Aceito em: 22/07/2014 